\title{
THE RELATIONSHIP BETWEEN SATISFACTION WITH LIFE AND EMPLOYEE ENGAGEMENT
}

Mr Anton Vorina, Professor, Vocational College of Economics, Celje, Slovenija, e-mail: anton.vorina@ guest.arnes.si

\begin{abstract}
Modern organizations need dedicated employees who are engaged with their work. The theme of employee engagement has generated a great deal of attention among many human resource practitioners and academic researchers across the world. In this paper we present an analysis the relationship between satisfaction with life and employee engagement in a casual sample of 1006 respondents in Slovenia. Based on multipla linear regression analysis, we found that relation between satisfaction with life and employee engagement is statistically significant (F: 381.80, Sig.: 0.000). Among two evaluated multiple regression models, as the most appropriate, the multiple linear regression model with one regressors (satisfaction with life) and sample size of 1006. We found out that the engagement of employee would increase if the satisfaction with life increase.
\end{abstract}

Keywords: satisfaction, employee, engagement, multiple linear regression

\section{Introduction}

The purpose of this paper is to investigate whether and how three selected variables influence the dependent variable under study defined as Y-a (engagement of empoloyee). The aim of the study is to contribute the understanding of how three independent variables $\left(\mathrm{X}_{1}\right.$ - a Dummy variable for gender; $\mathrm{X}_{1}=0$ for male; $X_{1}=1$ for female, $X_{2^{-}}$a variable for the amount of salary; $\mathrm{X}_{3^{-}}$a variable for a satisfaction with life) impact the $\mathrm{Y}$ variable based on linear regression models.

The main research hypothesis is that at least one independent of variables $\left(\mathrm{X}_{1}, \mathrm{X}_{2}, \mathrm{X}_{3}\right)$ is statistically significantly for explanation of variability in variable (Y- engagement of empoloyee).

Additional research hypothesis states that independent variable $\left(\mathrm{X}_{3}\right)$ is statistically significantly for explanation of variability in variable $(\mathrm{Y})$.

Research data has been acquired through use of a questionnaire. For data exploration using Excel, Megastat, IBM SPSS 20 and Gretl.
We used descriptive analysis and methods of multiple linear regression analysis.

\section{Literature overwiew}

The Dictionary of »Standard Slovenian word « »engagement « means "a high level of mental willingness, interest and involvement with something, someone who admires its work, work with the passion, a positive attitude to do anything" (http://bos.zrc-sazu.si/sskj.html). Kahn (1990, p. 694) was the first scholar to define "personal engagement" as the "harnessing of organization member's selves to their work roles: in engagement, people employ and express themselves physically, cognitively, emotionally and mentally during role performances".

Employee engagement, also called worker engagement, is a business management concept. An "engaged employee" is one who is fully involved in, and enthusiastic about their work, and thus will act in a way that furthers their organization's interests. Work engagement has been defined as "a positive, fulfilling workrelated state of mind that is characterized by vigor, dedication, and absorption" (Schaufeli et al., 2006, p. 702). Employee engagement is a distinct and unique construct that consists of cognitive, emotional, and behavioral components that are associated with individual role performance (Saks, 2006). Work engagement is defined as a positive, fulfilling, work-related state of mind that is characterized by vigor, dedication, and absorption (Schaufeli et al., 2002). Maslach et al. (2001) noted that engagement is characterized by energy, involvement, and efficacy - the direct opposites of the three burnout dimensions, exhaustion, cynicism and ineffectiveness.

There are empirical evidences, which show positive association between employee engagement and performance. According to the Job Demands - Resources Model, work engagement has a positive impact on job 
performance and employees who are engaged and perform well are able to create their own resources, which then foster engagement again over time and create a positive gain spiral (Bakker, Demerouti, 2008).

According to Blessing White's 2013 research report, the general findings are: while engagement and intent to stay are directly correlated, the specific dynamics of retention appear to vary significantly from one region of the world to the next; the dynamics of tenure, level and age remain the same - as people grow more experienced and vested in their work, or more senior in the organization, engagement increases; while gender is not a significant factor of engagement in western economies, large gaps in engagement levels between men and women are apparent in India, the Persian Gulf and South America (Employee Engagement Research Report Update- January 2013).

Schaufelli, et al. (2006) was found that engagement was weakly positively related with age; relationships between work engagement and gender were weak but equivocal, in the Australian, Canadian, and French samples, no gender differences were observed.

The Satisfaction With Life Scale (SWLS) is a global measure of happiness, defined as the cognitive, judgmental component of satisfaction with life. Research indicates that job satisfaction is significantly related to life satisfaction. Since the 1930's there has been a great deal of interest in the relationship between employee well-being and productivity. Hersey (1932, Zelenski et al, 2008) reported a positive relationship between daily emotions and performance.

The results of the study (Rathi, 2011) demonstrated positive relationship between psychological well-being and organizational commitment and its components, namely affective, continuance, and normative commitment.

Research (Grawitch et al., 2007) indicates that a high level of employee well-being leads to enhanced commitment to the organization. The relationship of employee well-being with work performance and various other organizational outcomes has been investigated by many researchers. Some researchers argued that psychological well-being causes higher work performance and organizational commitment (Warr, 2005, Rathi, 2011) whereas others argued that work performance and organizational commitment lead to well-being (Begley \& Czajka, 1993; Meyer \& Allen, 1997, Rathi, 2011).

\section{Exploratory data analysis}

Main results, findings and future research should be presented. We chose to investigate the population in Slovenia - »Savinjska« region. Occasional sample consisted of 1006 respondents.

The study included $463(46 \%)$ men and $538(53.5 \%)$ women, $5(0.5 \%)$ did not respond by gender, average period of employment is 16,35 years, $\mathrm{sd}=10.58$ years, average age of respondents is 38,63 years, $s d=10.12$ years.

The questionnaire consisted of 20 claims or questions which have been divided into three sections. The first section consisted of three demographic data (gender, period of employment and age). The second section consisted of twelve factors about employee engagement. We used a questionnaire from Gallup (http://www.gallup.com/strategicconsulting/1268 06/Q12-Meta-Analysis.aspx). The SWLS consists of 5-items: (In most ways my life is close to my ideal; The conditions of my life are excellent; I am satisfied with my life; So far I have gotten the important things I want in life; If I could live my life over, I would change almost nothing) that are completed by the individual whose life satisfaction is being measured. The assessment scale had a 5 points: 5 - Strongly agree; 4 Agree; 3 - Neither agree nor disagree; 2 Disagree; 1 - Strongly disagree. Interviewing was conducted from $3^{\text {th }}$ January 2012 to $15^{\text {th }}$ March 2012. Reliability of the scale is exemplary, if the Cronbach's alpha coefficient greater than or equal to 0.8 . The reliability of a questionnaire, which measure SWLS is Cronbach's alpha 0.823 (Tables 1 and 2), and for the engagement of employee (Tables 3 and 4) is Cronbach's alpha 0.87 which means a lot or exemplary reliability of measurement. 
Table 1: Case Processing Summary

\begin{tabular}{|l|l|r|r|}
\hline \multicolumn{2}{|c|}{} & \multicolumn{1}{|c|}{$\mathrm{N}$} & \multicolumn{1}{c|}{$\%$} \\
\hline Cases & Valid & 1000 & 99.4 \\
& & & \\
\cline { 2 - 4 } & Excluded & 6 & 0.6 \\
\cline { 2 - 4 } & Total & 1006 & 100.0 \\
\hline
\end{tabular}

Table 2: Reliability Statistics

\begin{tabular}{|l|c|}
\hline \multicolumn{2}{|c|}{ Reliability Statistics } \\
\hline $\begin{array}{l}\text { Cronbach's } \\
\text { Alpha }\end{array}$ & N of Items \\
\hline 0.823 & 5 \\
\hline
\end{tabular}

Table 3: Case Processing Summary

\begin{tabular}{|l|l|r|r|}
\hline \multicolumn{2}{|c|}{} & $\mathrm{N}$ & \multicolumn{1}{|c|}{$\%$} \\
\hline Cases & Valid & 999 & 99.3 \\
& & & \\
\cline { 2 - 4 } & Excluded & 7 & 0.7 \\
\cline { 2 - 4 } & Total & 1006 & 100.0 \\
\hline
\end{tabular}

Source: SPSS 20, Author's creation

Table 4: Reliability Statistics

\begin{tabular}{|l|c|}
\hline \multicolumn{2}{|c|}{ Reliability Statistics } \\
\hline $\begin{array}{l}\text { Cronbach's } \\
\text { Alpha }\end{array}$ & N of Items \\
\hline 0.870 & 12 \\
\hline
\end{tabular}

Source: SPSS 20, Author's creation

A depend variable is an engagement of employee, which was measured by the twelve factors, were added together, (summary) mentioned above. Independent variables are: $X_{1}$ gender; $\mathrm{X}_{2}-$ the amount of salary; $\mathrm{X}_{3}-\mathrm{SWLS}$ (summary 5 factors).

\section{Multiple linear regression models}

In general, multiple regression allows the researcher to ask (and hopefully answer) the general question "what is the best predictor of ...".
Of course, limitation of all regression techniques is that one can only ascertain relationships, but never be sure about underlying causal mechanism. For testing the first research hypotheses a multiple linear regression analysis using software Megastat, Excel, SPSS 20 and Gretl was applied. The general multiple linear regression population Model applied (1) is:

$$
y_{i}=\beta_{0}+\sum_{j=1}^{k} \beta_{j} x_{j, i}+e_{i}, \quad i=1,2, \ldots, n
$$

Regression parameters are estimated using minimum least squares (OLS) method. The Model with the OLS estimated parameters (2) is:

$$
\hat{y}_{i}=\hat{\beta}_{0}+\sum_{j=1}^{k} \hat{\beta}_{j} x_{j, i}, \quad i=1,2, \ldots, n
$$

The random error term (3) is estimated using:

$$
\hat{e}_{i}=y_{i}-\hat{y}_{i}
$$

The most important limit of the regression method is that only probable relationships are assumed, and one may never be sure about the true causal mechanism that lies behind. Regression diagnostics was conducted using coefficient of determination $R^{2}$, the $t$-test for testing the significance of each of the independent variables, and F-test in testing for overall regression. Results for two multiple regression models are given in Tables 3, 4 and 5. The two multiple OLS regression models were analysed, for studying the following:

Model I- Impact of $\mathrm{K}=3$ regressors on depend variable $Y,(n=1006)$. The linear multiple regression Model I (4) with estimated parameters is:

$\left(\hat{Y}=21.7-0.25 X_{1}+0.001 X_{2}+1.13 X_{a}\right)(4)$

$\mathrm{n}=1006, \mathrm{R}$-squared $=0.312$, Adjusted R-squares $=0.308$, Standard Error $=7.57$.

In Model I (Table 5) $31.2 \%$ of total sum of squares are explained by the estimated model. Variables $\mathrm{X}_{1}(\mathrm{p}$-value $=0.694), \mathrm{X}_{2}(\mathrm{p}$-value $=$ 0.090) are not statistically significant. In additional Model II, we excluded the variable $\mathrm{X}_{1}$ and $\mathrm{X}_{2}$. 
Table 5: Regression Model I: K=3, n=1006

\begin{tabular}{|c|c|c|c|c|}
\hline & Coeff. & $\begin{array}{c}\text { Standard } \\
\text { Error }\end{array}$ & t Stat & $\begin{array}{c}\text { P- } \\
\text { value }\end{array}$ \\
\hline Intercept & 21.697 & 1,581 & 13.72 & 0.000 \\
\hline $\mathrm{X}_{1}$ & 0.251 & 0.639 & 0.393 & 0.694 \\
\hline $\mathrm{X}_{2}$ & 0,001 & 0.001 & 1.696 & 0.090 \\
\hline $\mathrm{X}_{3}$ & 1.127 & 0.073 & 15.48 & 0.000 \\
\hline \multicolumn{5}{|c|}{ Source: Megastat, Gretl, Author's creation } \\
\hline
\end{tabular}

Model II (Table 6, 7 and 8) - Impact of $K=1$ regressors on depend variable $Y,(n=1006)$. The linear multiple regression Model II (5) with estimated parameters is:

$\left(\tilde{\mathrm{Y}}=23.60+1.074 \mathrm{X}_{\mathrm{a}}\right)$

$\mathrm{n}=1006, \mathrm{R}$-squared $=0.278$, Adjusted R-squares $=0.277$, Standard Error $=7.117$

$\mathrm{F}(1,234)=7.54, \mathrm{P}$ - value $=0.006$.

Table 6: Regression Model II: $\mathrm{K}=1, \mathrm{n}=1006$

\begin{tabular}{|c|c|c|c|c|}
\hline & $\mathrm{R}$ & $\begin{array}{c}\text { Adjusted } \\
\mathrm{R} \\
\mathrm{R}\end{array}$ & $\begin{array}{c}\text { Std. } \\
\text { Error of } \\
\text { the } \\
\text { Square } \\
\text { Square }\end{array}$ & $\begin{array}{c}\text { Eurbin- } \\
\text { Watson }\end{array}$ \\
\hline 0.527 & 0.278 & 0.277 & 7.39 & 1.54 \\
\hline
\end{tabular}

Source: Gretl, SPSS 20, Author's creation

Table 7: Regression Model II, F-test

\begin{tabular}{|l|r|r|r|r|}
\hline Model II & $\begin{array}{c}\text { Sum of } \\
\text { Squares }\end{array}$ & df & F & Sig. \\
\hline Regres. & 20845.948 & 1 & 381.8 & 0.000 \\
\hline Resid. & 54107.933 & 991 & & \\
\hline Total & 74953.881 & 992 & & \\
\hline
\end{tabular}

Source: SPSS 20, Author's creation

Table 8: Regression Model I: K=1, n=1006

\begin{tabular}{|c|c|c|c|c|}
\hline & Coeff. & $\begin{array}{c}\text { Standard } \\
\text { Error }\end{array}$ & t Stat & $\begin{array}{c}\text { P- } \\
\text { value }\end{array}$ \\
\hline Inter. & 23.60 & 0.910 & 25.93 & 0.000 \\
\hline $\mathrm{X}_{3}$ & 1.074 & 0.055 & 19.54 & 0.000 \\
\hline
\end{tabular}

Source: Megastat, Gretl, Author's creation
In Model II $27.8 \%$ of total sum of squares is explained by the estimated model. Variables $\mathrm{X}_{3} \quad(\mathrm{p}$-value $=0.000)$ is statistically significant at $5 \%$ significance level.

\section{The regression coefficient $\beta_{3}$ shows that if $X_{3}$, satisfaction with life, would increase, the regression value of engagement of employee would also increase.}

\section{Conclusion}

For 1006 respondents in Slovenia in Savinjska region, regression analysis of dependent variable Y- engagement of employee was conducted. Three independent variables considered are: $\mathrm{X}_{1^{-}}$gender; $\mathrm{X}_{2^{-}}$amount of salary; $\mathrm{X}_{3^{-}}$satisfaction with life. All data are based on author's research. Multiple linear regression Model I, with $\mathrm{n}=1006$ and $\mathrm{K}=3$ regressors, indicated that only variables $\mathrm{X}_{3}$ was statistically significant. Model II, with $\mathrm{n}=1006$ and $\mathrm{K}=1$ regressors, indicated that variables $X_{3}$ is statistically significant at $5 \%$ significance level. The F-test with F-statistics = F 381.8 and Pvalue $=0.000$ shows that overall regression is statistically significant at $5 \%$ significance level.

Finally, in this research, the first hypothesis was accepted: the main research hypothesis, which stated that at least one independent of variables $\left(\mathrm{X}_{1}, \mathrm{X}_{2}, \mathrm{X}_{3},\right)$ is statistically significantly for explanation of variability in variable $\mathrm{Y}$ - engagement of employee. The additional hypothesis, that that independent variable $\left(\mathrm{X}_{3}\right)$ is statistically significantly for explanation of variability in variable $\mathrm{Y}$ was also accepted.

We have come to similar conclusions as Zelenski et al., (2008) and (Rathi, 2011)

In further research would be interesting to include in the linear regression model other independent variables such as, (education of guest, marital status...). 


\section{References}

1. Bakker, A. B., Demerouti, E. (2008). Towards a model of work engagement. Career Development International, 13(3). 209-223.

2. Employee Engagement Research Report UpdateJanuary 2013. Retrieved 15 March 2013 from the website: http://www.blessingwhite.com/eee_report.asp.

3. Engagement. Ljubljana: ZRC SAZU. Retrieved 11 March 2013 from the website: http://bos.zrcsazu.si/sskj.html.

4. Grawitch, M.J., Gottschalk, M., \& Munz, D.C. (2006). The path to a healthy workplace: A critical review linking healthy workplace practices, employee well-being, and organizational improvements. Consulting Psychology Journal: Practice and Research, 58(3). 129-147.

5. Kahn, W. A. (1990). Psychological conditions of personal engagement and disengagement at work. Academy of Management Journal, 33(4). 692-724. Retrieved 21 March 2013 from the website: http://engagementresearch.wikispaces.com/file/view/Kahn+ (1990)_Psychological+conditions+of+personal+engagemen $\mathrm{t}+$ and+disengagement+at+work.pdf.

6. Maslach, C., Schaufelli, W. B. \& Leiter, M. P. (2001). Job burnout. Annual Review of Psychology, 52. 397-422.

7. Q12® Meta-Analysis. The Relationship Between Engagement at Work and Organizational Outcomes. Retrieved March 2013 from the website
http://www.gallup.com/strategicconsulting/126806/Q12Meta-Analysis.aspx.

8. Rathi, N. (2011). Psychological Well-Being and Organizational Commitment: Exploration of the Relationship. Working Paper No.106/2011. Retrieved 24 March 2013 from the website http://www.amrita.edu/sdg/pdf/ASB\%20Working\%20paper \%20series/MBA\%20book\%20106-

2011\%20Psychological\%20Well-

Being\%20and\%20Organizational\%20Commitment\%20Exp loration\%20of\%20the\%20Relationship.pdf

9. Saks, A. M. (2006). Antecedents and consequences of employee engagement. Journal of Managerial Psychology, 21(7). 600-619.

10. Schaufeli, W.B., Bakker, A.B. and Salanova, M. (2006). The measurement of work engagement with a short questionnaire: a cross-national study. Educational and Psychological Measurement, 66(4). 701-16.

11. Schaufeli, W.B., Salanova, M., Gonzalez-Roma, V. and Bakker, A.B. (2002). The measurement of engagement and burnout and: a confirmative analytic approach. Journal of Happiness Studies, (3). 71-92.

12. Zelenski, J. Murhpy. S. A. \& Jenkins D.A. (2008). The Happy-Productive Worker Thesis Revisited. Springer Science+Business Media B.V. 521-537. Retrieved 22 March 2013 from the website: ttp://www.sel.eesc.usp.br/informatica/graduacao/material/et ica/private/the_happy-

productive_worker_thesis_revisited.pdf. 